\title{
The way to a meat-eater's heart is through their stomach: Exposure to more appealing vegan food increases preference for meat-free options
}

\author{
Amy Bradford ${ }^{1}$, Anna Hancox ${ }^{2}$, \& Christopher Bryant ${ }^{2}$ \\ ${ }^{1}$ School of Psychology, University of Kent, Kent, United Kingdom \\ 2 Department of Psychology, University of Bath, Bath, United Kingdom
}

\begin{abstract}
Industrial animal agriculture harms the planet, human health, and animal welfare. Despite this, the public remains largely unwilling to forgo meat, most commonly because they are unwilling to give up the taste and sensory experience. However, rapidly improving meat alternatives means that the cost of forgoing meat is declining. We employed a $2 \times 2$ experimental design to examine the effects of exposure to images of appealing or unappealing meat or vegan food on (a) agreement with the statement that animals can feel pain, (b) estimates of how many animals are factory farmed, and (c) preference for meat or vegan food. Participants $(\mathrm{N}=469)$ were randomly assigned to one of the four experimental groups or a control group who saw no food. We found no significant difference in estimates of factory farming or animals' ability to feel pain between conditions. However, results did show that exposure to appealing (vs. unappealing) vegan food was associated with a significantly stronger preference for vegan food. We discuss these findings in the context of rapidly improving meat alternatives.
\end{abstract}

Keywords: meat; meat alternatives; vegetarianism; food choice; consumer behaviour 


\section{Introduction}

\subsection{Industrial animal agriculture}

Industrial animal agriculture poses several major issues to human health, the environment, and animal welfare. Although animal products constitute $37 \%$ of the protein and $18 \%$ of the calories of the world's diet, they contribute approximately $57 \%$ of the food system's emissions (Poore \& Nemecek, 2018). The Intergovernmental Panel on Climate Change's 2018 Special Report declared that all the paths consistent with keeping below $1.5^{\circ} \mathrm{C}$ of global warming include diets very low in animal products, whereas the paths consistent with exceeding that target include diets high in animal products (IPCC, 2018). In spite of this, consumer awareness of the issue remains low; those who are aware of the environmental impact of animal agriculture are in the range of $23 \%$ to $35 \%$ of those surveyed in the literature (Sanchez-Sabate \& Sabaté, 2019).

In addition to environmental concerns, the evidence is also clear that industrial animal agriculture has implications for public health. One particularly alarming example is the major contribution made by animal agriculture to antibiotic resistance (Landers et al., 2012). It is estimated that antibiotic use is equally as prevalent in livestock production and aquaculture as in the human population, and may be even higher (O'Neill, 2015). This is in spite of the fact that more caution has been urged in their use in order to preserve their future efficacy (McEwen, 2006; Lee, Cho, Jeong, \& Lee, 2013).

Perhaps the issue of greatest concern, however, is the capacity of animals to suffer immensely within the current system. The evidence for consciousness in mammals and birds is now incontrovertible (Low et al, 2012), and much evidence supports the presence of consciousness in fish (Brown, 2015; Sneddon, 2015). Yet of the hundreds of billions of animals reared for food annually, more than $90 \%$ are estimated to live out their lives in factory farms (Anthis, 2019; Sanders, 2020). At the end of their lives, these animals are killed in conditions so dire that substantial psychological distress has been documented in the slaughterhouse workers paid to carry out this task (Dillard, 2008). This raises grave ethical concerns about the suffering inflicted by animal agriculture.

\subsection{The psychology of meat eating}

In spite of these facts, the vast majority of people consume animal products on a regular basis. When asked about their perceptions of veganism, most meat-eaters say that it is difficult (Bryant, 2019), and those who expressed unwillingness to go vegan often cited taste as the main barrier (Humane League Labs, 2014a). Since these are seemingly self-interested justifications, and people generally consider themselves moral (Tappin \& McKay, 2017), meat-eaters who wish to maintain their 
positive self-perceptions need to justify the morality of their actions, which leads to substantial motivated reasoning on the topic of meat consumption (Rothgerber, 2020).

Bastian and Loughnan (2017) described this phenomenon of simultaneous discomfort and complicity as "the meat paradox". The authors posited several strategies that may be employed to resolve the cognitive dissonance produced from this paradox, such as denying that animals are harmed in the process (e.g. asserting that animals lack the capacity for pain), denying personal responsibility for harm (e.g. claiming that animal production consumption is necessary for their health), and denying the extent of their involvement (e.g. under-reporting their animal product consumption). The authors further note that people seek to avoid cognitive dissonance in the first place, by forming habits and rituals around animal product consumption, looking to social norms for reassurance, and avoiding evidence of the source of their food (for example, body parts such as eyes which could serve as reminders of the animal's individuality).

One form of motivated reasoning is to deny that animals can suffer. For instance, when people are given beef to consume (compared to nuts), they subsequently narrow their moral concern for cows (Loughnan, Haslam, \& Bastian, 2010). Similarly, those preparing to eat meat are motivated to deny animal mind - and, perhaps more significantly, feel better for doing so (Bastian, Loughnan, Haslam, \& Radke, 2012).

We can see further evidence of motivated reasoning with respect to animal product consumption from survey data. One survey of adults in the US found that $58 \%$ agreed with the statement "most farmed animals are treated well", and $75.4 \%$ agreed with the statement "the animal-based foods I purchase (meat, dairy, and/or eggs) usually come from animals that are treated humanely" (Reese, 2017). In reality, the proportion of animals reared for food in the US which are on factory farms is over 99\% (Reese, 2017). Mistrust of animal welfare activism may serve to shield these erroneous beliefs from deeper consideration (Buddle, Bray \& Ankeny, 2018).

Furthermore, Reese (2017) also reported that $69.6 \%$ expressed discomfort with the current methods of animal farming, with $48.9 \%$ supporting a ban of factory farming. So many people holding these views in spite of eating factory farmed animals suggests that they are, to a large extent, engaging in motivated reasoning.

Some may opt to actively ignore the topic (Onwezen \& van der Weele, 2016). It has been noted that consumers making food choices will refuse health-related information that would likely sway their decision (Woolley \& Risen, 2018; Gaspar et al., 2016). The same is true when it comes to the ethical dimension of their choice: meat-eaters are likely to avoid reading booklets featuring images of suffering animals, yet these very images are most effective in swaying them away from meat consumption (Humane League Labs, 2014b). Likewise, viewers of videos depicting 
factory farm conditions were more likely to stop watching compared with viewers of other videos, but were also more likely to consider reducing their animal product consumption (Faunalytics, 2014).

It appears that many people hold dissonant views to justify their meat consumption. However, in the presence of ever-improving alternatives to meat, this paradigm may change. If there is little to lose from avoiding meat, people will presumably lack the motivation to engage in motivated reasoning about eating animals.

\subsection{Meat alternatives}

Animal product alternatives provide a possible remedy to the perceived difficulty of eliminating animal consumption. As well as having a far lower environmental impact compared to their animal-based counterparts, plant-based meats tend to have favorable nutritional profiles, particularly with respect to saturated fat and cholesterol (Bohrer, 2019; Petersen, Hartmann \& Hirsch, 2021; Saerens et al., 2021; Saget et al., 2021). Beyond existing plant-based alternatives is the development of cultivated meat grown from animal cells, which is likewise expected to be substantially more sustainable than existing industrial farming practices (Odegard \& Sinke, 2021; Post et al., 2020). This avenue provides significant promise for moving heavy meat-eating consumers away from conventional animal products in a way which plant-based products appear not to (Bryant et al., 2019).

As well as replicating the taste and sensory experience of animal products, animal product alternatives can act as direct substitutes, and are therefore extremely convenient (Michel et al., 2021). Convenience is an important factor in food choice (Steptoe et al., 1995; Fotopoulos et al., 2009), and is one of the major reasons given by ex-vegans for returning to eating meat (Asher et al., 2014). Wider availability of meatless dishes is associated with greater uptake of meatless options (Bianchi et al., 2018; Garnett et al., 2019), suggesting that wider availability of animal product alternatives is vital. Since many meat-eaters already agree that vegan diets are ethical, good for the environment, and healthy (Bryant, 2019), providing high-quality accessible alternatives could be the key catalyst to shifting more people away from meat.

Consumption of meat substitutes negatively correlates with meat consumption, and those who consume substitutes with the lowest frequency indicate a preference for the sensory qualities of meat (Hoek et al., 2011). As these are strong motivations for food choice, it follows that improving meat substitutes along these lines would have the effect of reducing meat consumption via substitution (Januszewska et al., 2011; Bryant, 2019). Indeed, if meat alternatives of sufficiently high quality are available conveniently and at low prices, one would expect that the average person loses their motivation to argue in favour of meat consumption. However, there is currently no direct evidence of this effect within the psychological literature. 


\subsection{Hypotheses}

Therefore, this study sought to test the hypothesis that seeing more appealing meat alternatives lead to a stronger preference for meat alternatives over meat. Relatedly, we sought to test the hypothesis that this shift in preference would also affect people's estimates of how much meat comes from factory farms via a process of motivated reasoning (i.e. people would give lower estimates of factory farming if they perceived meat alternatives to be less appealing). Specifically, we tested the following hypotheses:

1. We will observe a stronger preference for vegan food over meat

a. in individuals who are exposed to appealing vs. unappealing vegan food.

b. in individuals who are exposed to unappealing vs. appealing meat.

c. in individuals who are exposed to appealing vegan food vs. control.

d. in individuals who are exposed to unappealing meat vs. control.

2. We will observe lower estimates of animals' ability to feel pain

a. in individuals who are exposed to appealing vs. unappealing vegan food.

b. in individuals who are exposed to unappealing vs. appealing meat.

c. in individuals who are exposed to appealing vegan food vs. control.

d. in individuals who are exposed to unappealing meat vs. control.

3. We will observe lower estimates of the prevalence of factory farming

a. in individuals who are exposed to appealing vs. unappealing meat.

b. in individuals who are exposed to unappealing vs. appealing vegan food.

c. in individuals who are exposed to unappealing vegan food vs. control.

d. in individuals who are exposed to appealing meat vs. control.

\section{Methods}

\subsection{Procedure}

This study received ethical approval from the University of Bath's Psychology Research Ethics Committee (PREC 20-223). Participants were recruited from Prolific to complete an online survey administered via Qualtrics.

The survey used a $2 \times 2$ between-groups experimental design (plus a control group; see Table 1). The independent variables in this design were food type (meat and vegan) and appeal (appealing and unappealing). The dependent variables were preference for meat or vegan food, estimates of animals' ability to feel pain, and estimates of factory farming (see Table 2). 
Table 1: Images used in the four experimental conditions shown alongside their captions (a fifth control condition showed no image).

\begin{tabular}{|c|c|c|}
\hline Meat & Unappealing & Appealing \\
\hline \multirow{5}{*}{ Vegan } & Look at this photo of fried chicken. & Look at this photo of fried chicken. \\
\hline & Look at this photo of a vegan burger. & Look at this photo of a vegan burger. \\
\hline Control & & \\
\hline
\end{tabular}

Table 2: Key outcome variables with question wording and answer format.

\begin{tabular}{|l|l|l|}
\hline Variable & Question & Answers \\
\hline Appeal & $\begin{array}{l}\text { How appealing do you find the } \\
\text { food in this image? }\end{array}$ & $\begin{array}{l}\text { Sliding 0-100 scale labeled at } \\
\text { each end 'Very unappealing' (0) } \\
\text { and 'Very appealing' (100) }\end{array}$ \\
\hline $\begin{array}{l}\text { Preference for } \\
\text { meat or vegan } \\
\text { food }\end{array}$ & $\begin{array}{l}\text { Would you prefer to eat a meat } \\
\text { meal or a plant-based meal? }\end{array}$ & $\begin{array}{l}\text { Sliding 0-100 scale labeled at } \\
\text { each end 'Strongly prefer meat' } \\
\text { (0) and 'Strongly prefer plant- } \\
\text { based' (100) }\end{array}$ \\
\hline $\begin{array}{l}\text { Estimate of } \\
\text { animals' ability } \\
\text { to feel pain }\end{array}$ & $\begin{array}{l}\text { To what extent do you agree or } \\
\text { disagree with the following } \\
\text { statement: Animals can feel pain. }\end{array}$ & $\begin{array}{l}\text { Sliding 0-100 scale labeled at } \\
\text { each end 'Disagree' (0) and } \\
\text { 'Agree' (100) }\end{array}$ \\
\hline $\begin{array}{l}\text { Factory farming } \\
\text { estimate }\end{array}$ & $\begin{array}{l}\text { Estimate what percentage of meat } \\
\text { sold in the UK is factory farmed. }\end{array}$ & $\begin{array}{l}\text { Sliding 0-100 scale labeled } \\
\text { 'Percentage factory farmed' }\end{array}$ \\
\hline
\end{tabular}


First, participants completed a demographic survey, answering questions about their age, gender, current diet, religion, level of education, and political views. Next, they were randomly assigned to one of the five groups represented in Table 1. Two groups viewed images of fried chicken: one visually appealing, and one unappealing. Another two groups viewed an image of a vegan burger, again with one group presented with an appealing picture and another an unappealing picture. The final group was the control group, who were not presented with any picture.

Those who were shown food images were asked to rate how appealing the food was using a $0-100$ slider where $0=$ unappealing and $100=$ appealing. All respondents were then asked to estimate what percentage of meat sold in the UK they thought was derived from factory farms, again using a 0-100 slider. Respondents were also asked how much they agreed that animals can feel pain, using a 0-100 slider (disagree-agree). They then rated their preferences for a plant-based or a meat meal on a $0-100$ slider where $0=$ Strongly prefer meat and $100=$ Strongly prefer plantbased (see Table 2). Finally, participants were debriefed, compensated, and thanked for their time.

\subsection{Participants}

Participants were recruited through the online platform, Prolific. Participants were each offered $£ 0.50$ to take part in a 4 minute survey. We aimed for 500 participants such that, following randomisation to experimental groups, each group would contain approximately 100 participants. This sample size would allow us to detect small-tomedium effect sizes using ANOVAs and pairwise comparisons according to figures presented by Cohen (1992).

We used a stratified sampling approach, aiming for a sample representative of the United Kingdom in terms of gender and age groups. We excluded vegetarians and vegans ( $n=31$ ) since our main interest is meat-eaters' preferences, and the key outcome variable of preference for meat vs. a plant-based meal would not be relevant for meat-avoiders. This resulted in a representative sample of 469 participants, as shown in Figure 1 and Table 3. 
Figure 1: Population pyramid showing the age and gender of study participants.

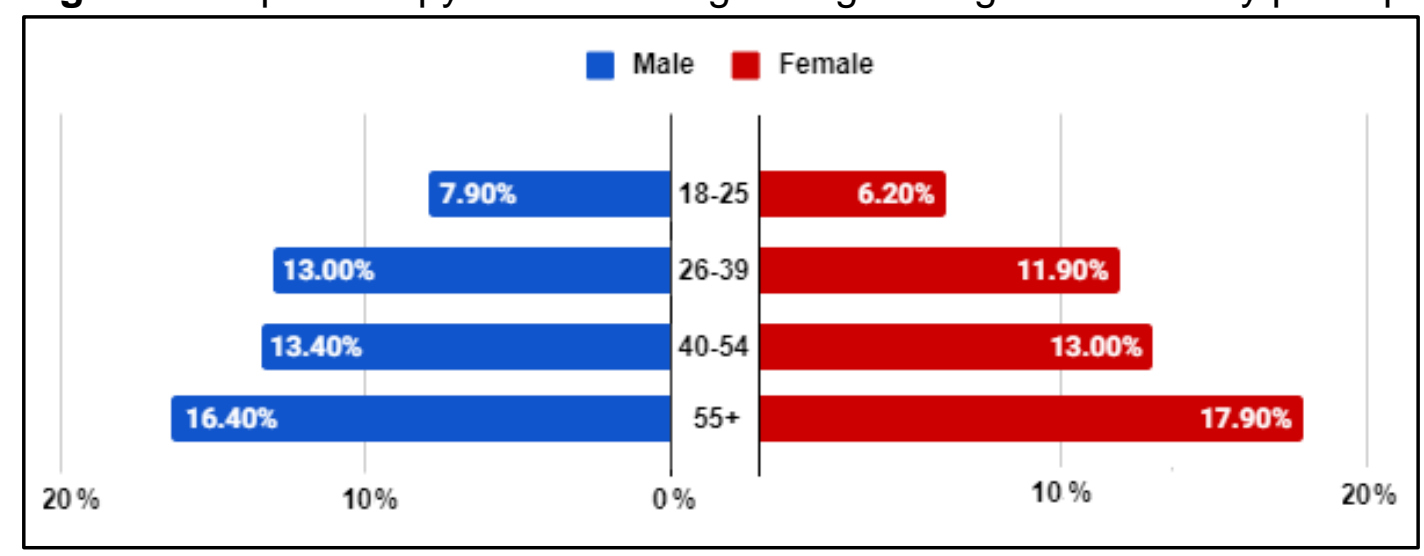

Table 3: Participant demographics.

\begin{tabular}{|l|r|l|r|}
\hline \multicolumn{2}{|c|}{ Diet } & \multicolumn{2}{c|}{ Education } \\
\hline Omnivore & $73.9 \%$ & Some school & $0.9 \%$ \\
\hline Flexitarian & $20.1 \%$ & GCSEs/secondary school & $17.9 \%$ \\
\hline Pescetarian & $6.0 \%$ & A-Levels or equivalent & $31.8 \%$ \\
\hline $\begin{array}{l}\text { Vegetarian (removed from } \\
\text { sample) }\end{array}$ & - & Undergraduate degree & $36.0 \%$ \\
\hline Vegan (removed from sample) & - & Postgraduate degree & $13.4 \%$ \\
\hline \multicolumn{2}{|c|}{ Religion } & Political views \\
\hline Christian & $40.7 \%$ & Far left & $3.8 \%$ \\
\hline Muslim & $3.2 \%$ & Left & $12.6 \%$ \\
\hline Hindu & $0.9 \%$ & Left-leaning & $25.4 \%$ \\
\hline Buddhist & $0.9 \%$ & Centrist & $38.0 \%$ \\
\hline Jewish & $0.2 \%$ & Right-leaning & $15.1 \%$ \\
\hline Agnostic & $15.6 \%$ & Right & $4.3 \%$ \\
\hline Atheist & $33.5 \%$ & Far right & $0.9 \%$ \\
\hline Other & $5.1 \%$ & & \\
\hline
\end{tabular}

\subsection{Analysis}

We used a series of one way between-groups ANOVAs to compare key outcomes between experimental groups. In particular, we compared experimental groups on 
subjective appeal of the images as a manipulation check to verify that the appealing images were judged to be more appealing than the unappealing images. We also compared experimental groups on measures of estimates of factory farming, and on preference for meat or vegan food. These served as the main analyses which would detect whether the different images caused participants to prefer vegan food more strongly, or to change their estimates of factory farming through a motivated reasoning process.

\section{Results}

We first present the results of all key outcome variables across conditions in Table 4, and then present graphs and interpret each of these variables against our hypotheses.

Table 4: Key outcome measures across experimental conditions.

\begin{tabular}{|c|c|c|c|c|c|}
\hline & $\begin{array}{c}\text { Control } \\
(\mathrm{M}, \mathrm{SD}, 95 \% \mathrm{Cl})\end{array}$ & $\begin{array}{c}\text { Appealing } \\
\text { chicken } \\
(\mathrm{M}, \mathrm{SD}, 95 \% \mathrm{Cl})\end{array}$ & $\begin{array}{c}\text { Unappealing } \\
\text { chicken } \\
(\mathrm{M}, \mathrm{SD}, 95 \% \mathrm{Cl})\end{array}$ & $\begin{array}{c}\text { Appealing } \\
\text { vegan } \\
(\mathrm{M}, \mathrm{SD}, 95 \% \mathrm{Cl})\end{array}$ & $\begin{array}{c}\text { Unappealing } \\
\text { vegan } \\
(\mathrm{M}, \mathrm{SD}, 95 \% \mathrm{Cl})\end{array}$ \\
\hline $\mathbf{n}$ & 92 & 90 & 97 & 94 & 96 \\
\hline $\begin{array}{l}\text { Appeal }^{*} \\
F(3,373)=11.779 \\
p<0.001 \\
\eta^{2}=0.087\end{array}$ & - & $\begin{array}{c}55.47^{\mathrm{a}} \\
(28.38) \\
{[49.52-61.41]}\end{array}$ & $\begin{array}{c}44.11^{\mathrm{b}} \\
(29.88) \\
{[38.09-50.14]}\end{array}$ & $\begin{array}{c}62.43^{a} \\
(25.93) \\
{[57.11-67.74]}\end{array}$ & $\begin{array}{c}41.25^{\mathrm{b}} \\
(27.71) \\
{[35.63-46.87]}\end{array}$ \\
\hline $\begin{array}{l}\text { Preference }^{\star} \\
F(4,464)=3.488, \\
p=0.008, \\
\eta^{2}=0.029\end{array}$ & $\begin{array}{c}44.04^{\mathrm{ab}} \\
(29.38) \\
{[37.96-50.13]}\end{array}$ & $\begin{array}{c}41.78^{\mathrm{ab}} \\
(26.66) \\
{[36.19-47.36]}\end{array}$ & $\begin{array}{c}39.25^{\mathrm{a}} \\
(28.11) \\
{[33.58-44.91]}\end{array}$ & $\begin{array}{c}52.73^{\mathrm{b}} \\
(32.52) \\
{[46.07-59.39]}\end{array}$ & $\begin{array}{c}39.06^{\mathrm{a}} \\
(29.23) \\
{[33.14-44.98]}\end{array}$ \\
\hline $\begin{array}{l}\text { Factory Farming } \\
\text { Estimate } \\
F(4,464)=1.806 \\
p=0.127 \\
\eta^{2}=0.015\end{array}$ & $\begin{array}{c}65.47^{a} \\
(18.34) \\
{[61.67-69.27]}\end{array}$ & $\begin{array}{c}70.84^{\mathrm{a}} \\
(16.53) \\
{[67.38-74.31]}\end{array}$ & $\begin{array}{c}69.41^{a} \\
(16.64) \\
{[66.06-72.77]}\end{array}$ & $\begin{array}{c}65.89^{a} \\
(17.50) \\
{[62.31-69.48]}\end{array}$ & $\begin{array}{c}66.44^{a} \\
(15.95) \\
{[63.21-69.67]}\end{array}$ \\
\hline $\begin{array}{l}\text { Estimate of } \\
\text { Animals' Ability } \\
\text { to Feel Pain } \\
F(4,464)=1.663 \\
p=0.157 \\
\eta^{2}=0.014\end{array}$ & $\begin{array}{c}93.39^{a} \\
(16.79) \\
{[89.91-96.67]}\end{array}$ & $\begin{array}{c}94.90^{\mathrm{a}} \\
(9.96) \\
{[92.81-96.98]}\end{array}$ & $\begin{array}{c}96.70^{\mathrm{a}} \\
(6.51) \\
{[95.97-97.98]}\end{array}$ & $\begin{array}{c}96.45^{\mathrm{a}} \\
(11.59) \\
{[94.07-98.82]}\end{array}$ & $\begin{array}{c}93.27^{a} \\
(13.82) \\
{[90.47-96.07]}\end{array}$ \\
\hline
\end{tabular}

Asterisks mark variables which differ significantly between conditions. Within rows, shared superscript letters indicate no significant difference between conditions for this variable. 
Figure 2: Subjective appeal ratings for the food shown in different conditions.

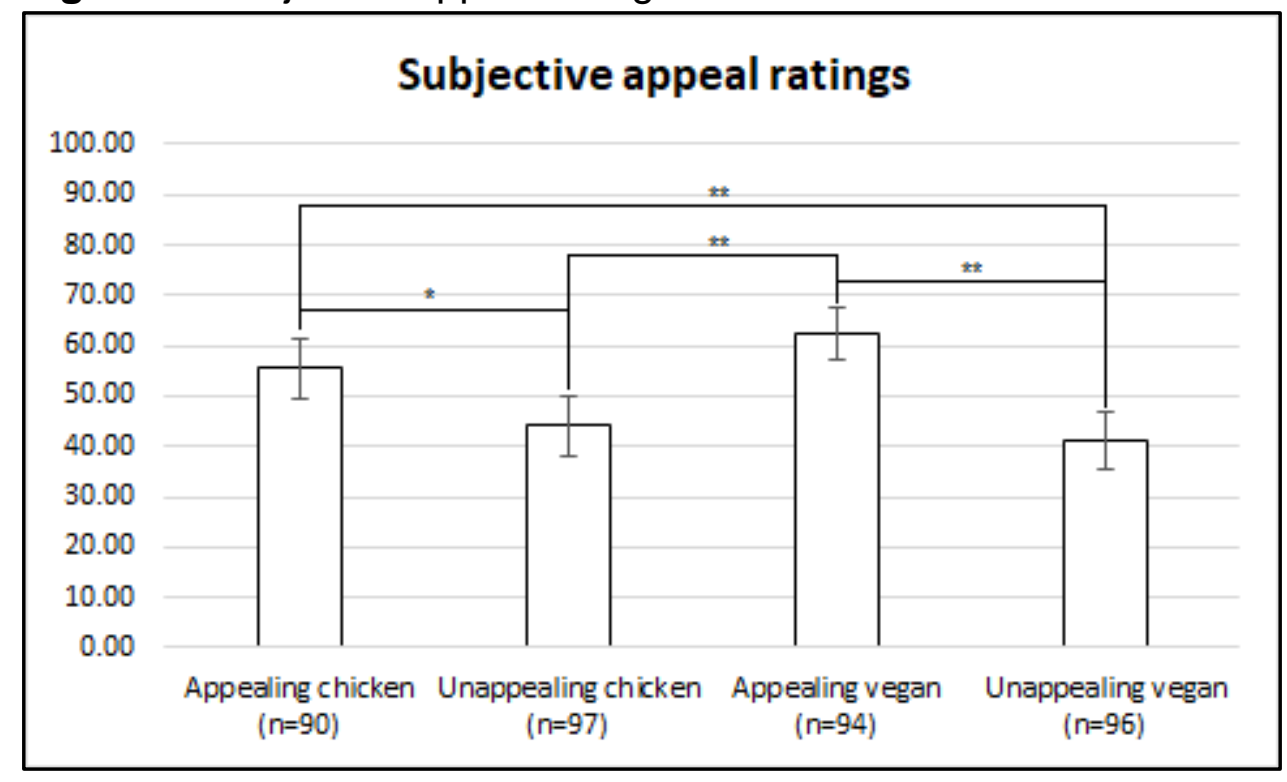

${ }^{*} p<0.05,{ }^{* *} p<0.01$

As shown in Table 4 and Figure 2, we observed a significant difference in the subjective appeal of the images shown such that the appealing chicken and appealing vegan photos were perceived as significantly more appealing than the unappealing chicken and the unappealing vegan photos. This functioned as a manipulation check, and confirmed that the appealing photos were indeed perceived as more appealing than the unappealing photos.

Figure 3: Average preference for a plant-based meal over a meat meal in each condition $(0=$ Strongly prefer meat, $100=$ Strongly prefer plant-based $)$

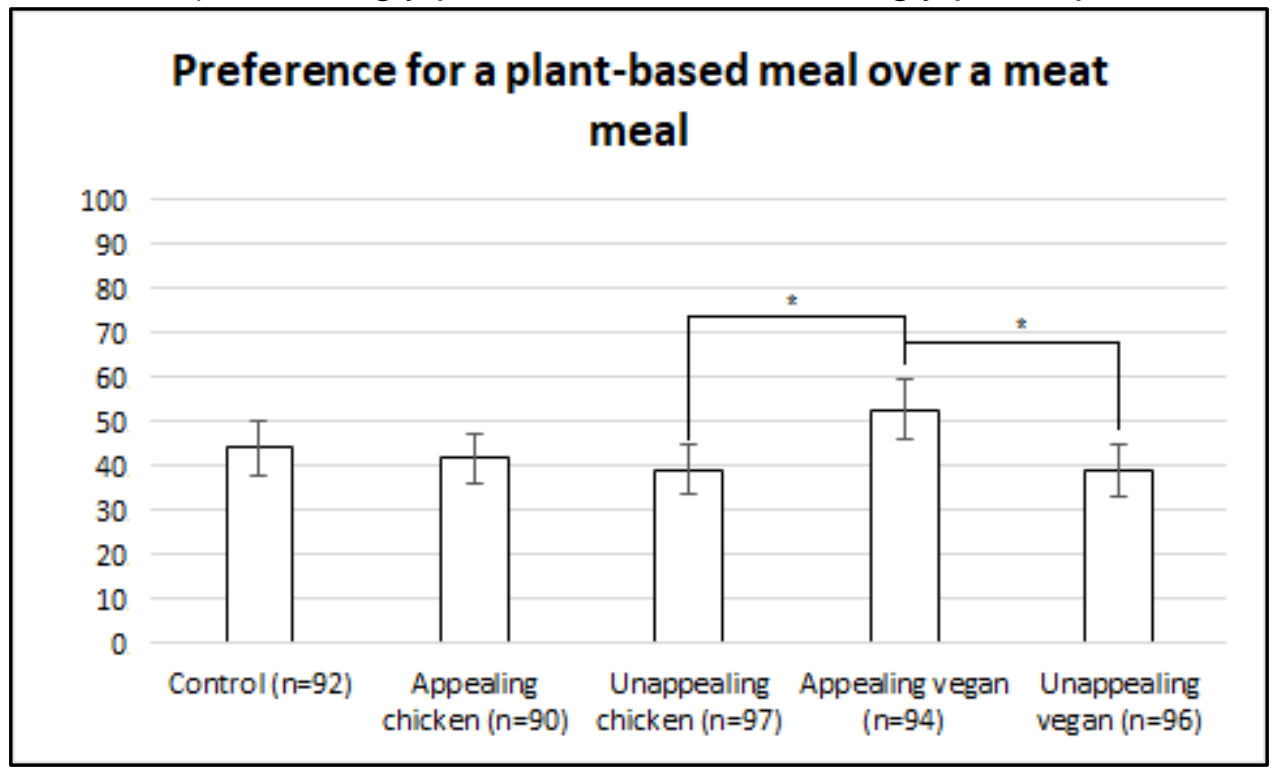

${ }^{*} p<0.05,{ }^{* *} p<0.01$

Figure 3 and Table 4 show that the appealing vegan food resulted in the strongest preference towards a plant-based meal over a meat meal, and this was significantly 
different from the unappealing vegan food, and the unappealing chicken. This finding supported our hypothesis $1 \mathrm{a}$, that individuals exposed to appealing vegan food would have a stronger preference for vegan food over meat compared to those exposed to unappealing vegan food.

However, the preference was not significantly different from the control group, thus failing to support our hypothesis 1c. Furthermore, there were no significant differences in preference for vegan food between those in the appealing chicken, unappealing chicken, or control groups, thus failing to support hypotheses $1 \mathrm{~b}$ and $1 d$.

Figure 4: Estimates of animals' ability to feel pain in each condition.

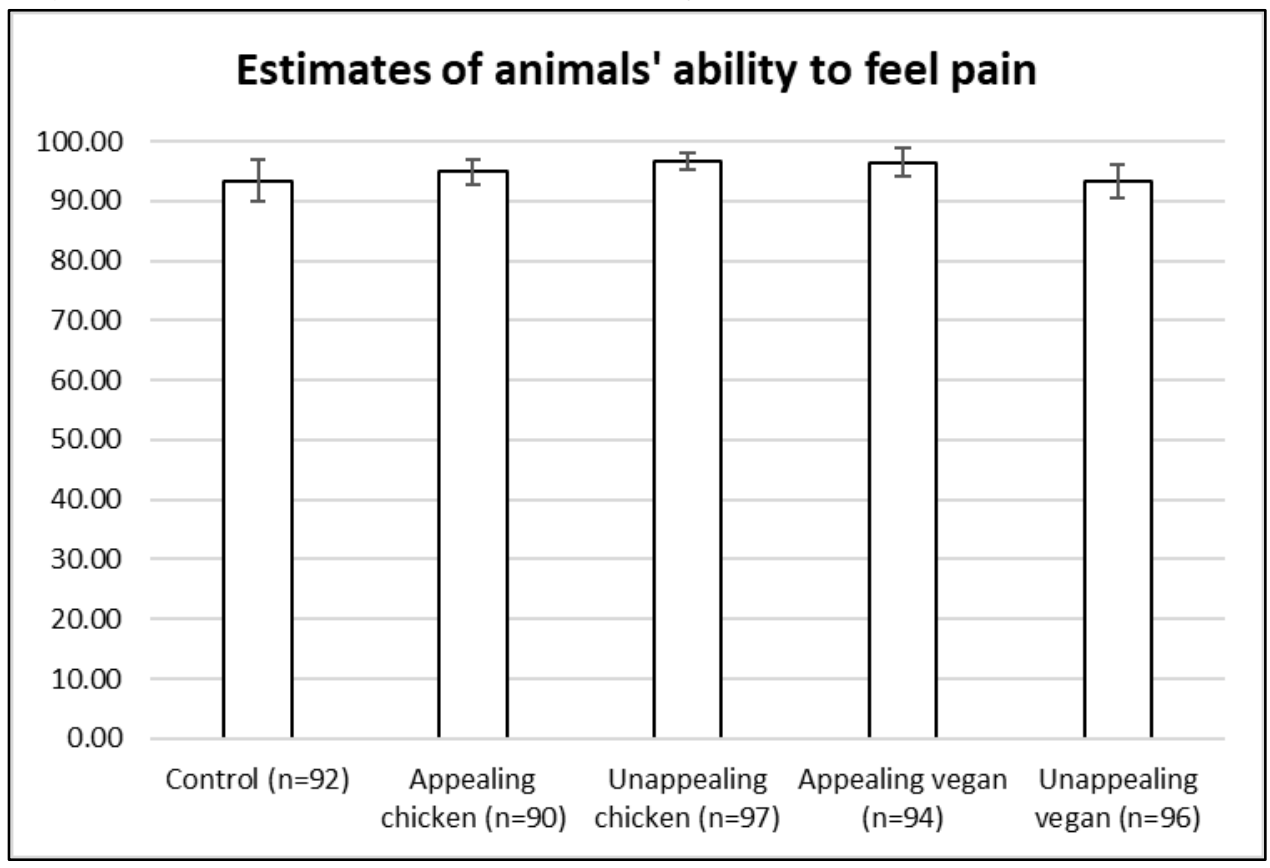

${ }^{*} p<0.05,{ }^{* *} p<0.01$

As shown in Figure 4 and Table 4, there was no significant difference in respondents' estimates of animals' ability to feel pain between conditions, thus failing to support our hypotheses $2 \mathrm{a}, 2 \mathrm{~b}, 2 \mathrm{c}$, and $2 \mathrm{~d}$. 
Figure 5: Estimates of the percentage of UK meat from factory farms in each condition.

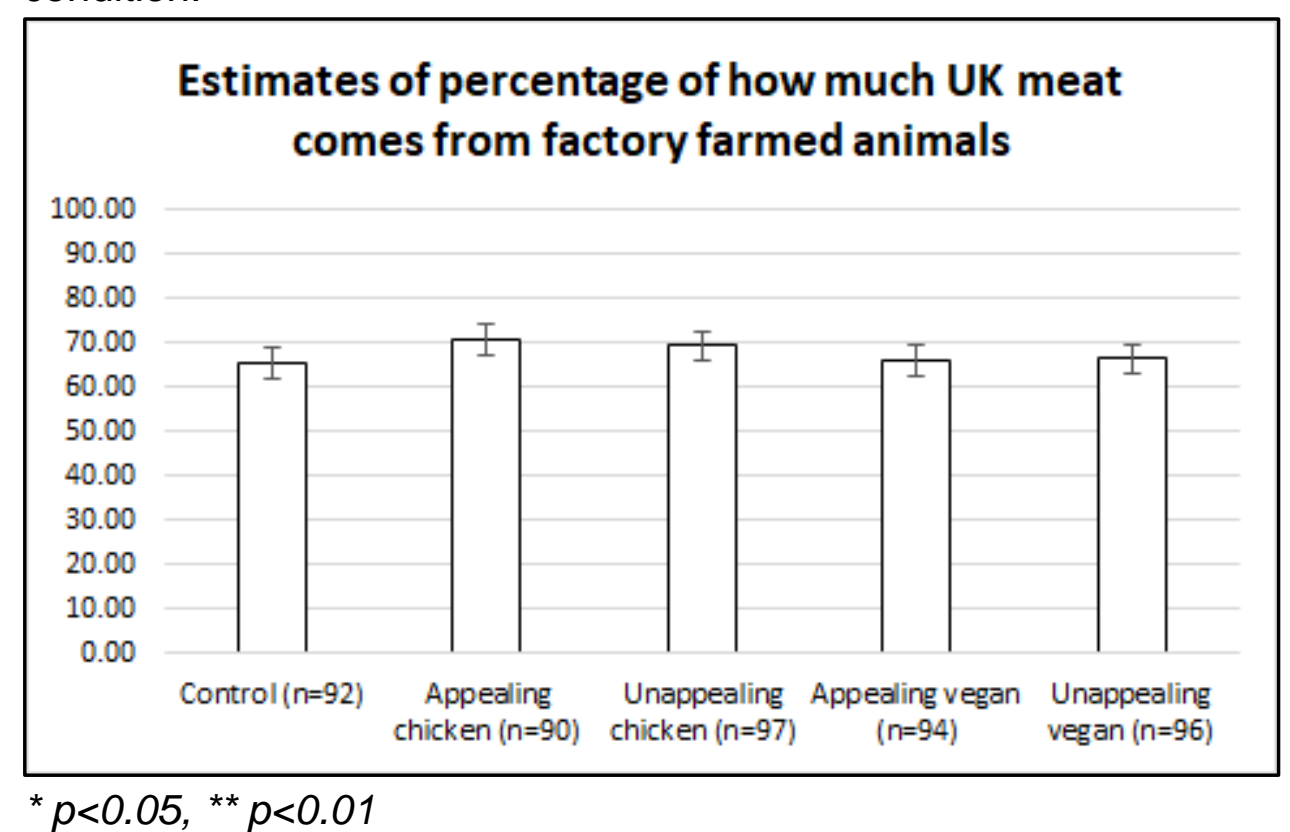

Figure 5 and Table 4 show the mean estimates for the percentage of meat sold in the UK which comes from factory farms across conditions. As shown, there was no significant difference between the conditions on this outcome measure, thus failing to support our hypotheses 3a, 3b, 3c, and 3d.

\section{Discussion}

Overall, the results partly supported our first set of hypotheses about preferences for vegan food (in particular H1a was supported, but not $\mathrm{H} 1 \mathrm{~b}-\mathrm{H} 1 \mathrm{~d}$ ), but did not support our second and third sets of hypotheses about motivated reasoning ( $\mathrm{H} 2 \mathrm{a}-\mathrm{H} 3 \mathrm{~d})$. This means that, while the appealing/unappealing meat/vegan food did not affect participants' estimates of factory farming, we did find evidence that seeing appealing vegan food resulted in significantly higher preference for vegan food compared to seeing unappealing vegan food. We discuss these results in further detail here, including interpretations, limitations, and ideas for future research.

\subsection{Motivated reasoning}

We did not find any difference between the experimental conditions with respect to participants' estimates of the percentage of UK meat coming from factory farms or perceptions of animals' ability to feel pain. These results differ from Loughnan, Haslam and Bastian (2010), who found that consumption of beef jerky (vs. nuts) did activate motivated reasoning, decreasing subsequent evaluations of the moral status of cows. This difference is most likely due to shortcomings in the present study - in particular, we only presented participants with images rather than actually having them eat the food. Furthermore, we used objective and verifiable outcome measures 
(animal ability to feel pain and percentage of animals factory farmed) rather than subjective measures (moral consideration of animals) which may have yielded more variance, and be more able to be manipulated in line with motivated reasoning.

It could be the case that, although participants had the motivation to deny the extent of factory farming, they did not possess enough necessary background information to justify this denial. Evidence for this explanation comes from research demonstrating that people only employ motivated reasoning when provided (tenuous) justifications with which to do so (Blanton \& Gerrard, 1997). Subjects typically employ 'non-diagnostic' information to justify their motivated reasoning - for example, given additional information about the nutritional content, participants might reason 'This chicken is quite low in salt, therefore it probably came from a free range farm'. In reality, these facts are completely unconnected, but individuals may nonetheless need some apparent justification upon which to base their motivation. Since participants in the present study were not given additional information about animal farming or welfare, they lacked the necessary pretext for altering their factory farming estimates or perceptions of animal pain.

A good example of non-diagnostic information for this paradigm would be country of origin, since consumers seem to believe (often falsely) that farming in their country is humane (Which?, 2018). Consumer research has reported Scottish consumers holding the false belief that no factory farming occurs in Scotland (McEachern \& Seaman, 2005). One study reported survey data on perceptions of animal welfare from four different European countries, and found that each of them believed their own country to have the superior animal welfare standards (Ngapo et al., 2003). It is therefore entirely likely that consumers use country of origin labels to make faulty inferences about animal welfare.

Notably, participants in all conditions estimated that around $70 \%$ of UK meat comes from factory farms, which is similar to the $73 \%$ figure that is presented in the top Google hit for this question (Compassion in World Farming, n.d.), suggesting that they may have tried to verify this objective answer. Other estimates of this figure may vary, and are dependent on the farming practices in countries from which meat is imported as well as UK farms.

\subsection{Preference for vegan food}

Our hypotheses about preferences for vegan food were partially supported. In particular, those who saw the appealing vegan food reported a significantly stronger preference for vegan food compared to those who saw the unappealing vegan food, and those who saw unappealing chicken (but not compared to the control). This result suggests that more visually appealing vegan options lead to more people preferring vegan food - the first time that a direct link has been demonstrated between these two factors. 
Vegan meat alternatives are unfamiliar to most people (Gallup, 2020), and therefore consumer perceptions of these products are likely more malleable than perceptions of meat. The preference for visually appealing vegan food over the visually unappealing image suggests that the marketing of meat alternatives is critical for encouraging increased uptake of veganism. Taste is a frequently cited barrier to the adoption of a vegan diet (Hoek et al., 2011; Hunter \& Röös, 2016; Michel et al., 2021; Rosenfeld \& Tomiyama, 2020), but the rise of meat alternatives which are increasing in quality rapidly (Bryant \& Sanctorum, 2020) may be able to overcome this.

Preference for meat or vegan food was not affected, however, by the presentation of the different meat images. Increased familiarity with meat as a food group compared to vegan food may have made participants' preferences less sensitive to changes in the presentation of meat. This is similar to the finding of Bekker et al. (2017), who noted that positive/negative information about cultured meat tended to change attitudes in the relevant direction, but the effect was weaker for people who had a higher level of prior familiarity with cultured meat. In short, consumers have wellestablished expectations of meat, but for meat alternatives, first impressions matter.

The names and descriptions of the products may also play a role, in addition to their actual sensory attributes; emphasising the appealing aspects of the product in question could substantially increase interest in vegan food (Bacon et al, 2018; Turnwald et al., 2017; Vennard et al., 2018).

\subsection{Limitations}

The study has some limitations worth addressing. First, the responses observed in this study (an online experiment) may not necessarily translate into real choices, since the study does not seek to simulate real-world choice situations. Secondly, we might have achieved more variance in our key dependent variables had we selected a more subjective measure (e.g. a cow's moral worth, rather than the percentage of animals factory farmed or animals' ability to feel pain, which are objective and verifiable.) These limitations in the design likely led to our failure to replicate motivated reasoning demonstrated in previous studies.

\subsection{Future research}

Future research should continue to develop more, better, and cheaper meat alternatives. Sensory and consumer researchers can support this work by identifying what aspects of meat alternatives make them more appealing. Factors like taste, texture, and smell, are likely important to get right (see Fiorentini, Kinchla \& Nolden, 2020), as well as price and convenience. This research suggests that the appearance of vegan alternatives is also important in appealing to meat-eaters. 
Moreover, although we failed to demonstrate the impact of meat alternatives on motivated reasoning in this study, it is possible that a similar effect could be shown given the right parameters. In particular, similar research in the future should consider providing additional (non-diagnostic) information about the meat alternatives, or use outcome measures with greater variance. 


\section{References}

Anthis, K. (2019). Global Farmed \& Factory Farmed Animals Estimates. Sentience Institute. Accessed 29 November 2020 at https:/www.sentienceinstitute.org/globalanimal-farming-estimates

Asher, K., Green, C., Gutbrod, H., Jewell, M., Hale, G., \& Bastian, B. (2014). Study of current and former vegetarians and vegans. Humane Research Council. https://faunalytics.org/a-summary-of-faunalytics-study-of-current-and-formervegetarians-and-vegans/

Bacon, L., J. Wise, S. Attwood \& D. Vennard. (2018). The Language of Sustainable Diets: A Field Study Exploring the Impact of Renaming Vegetarian Dishes on U.K. Café Menus. World Resources Institute. https://www.wri.org/publication/languagesustainable-diets

Bastian, B., \& Loughnan, S. (2017). Resolving the meat-paradox: A motivational account of morally troublesome behavior and its maintenance. Personality and Social Psychology Review, 21(3), 278-299. doi:10.1177/1088868316647562

Bastian, B., Loughnan, S., Haslam, N., \& Radke, H. R. (2012). Don't mind meat? The denial of mind to animals used for human consumption. Personality and Social Psychology Bulletin, 38(2), 247-256. https://doi.org/10.1177/0146167211424291

Bekker, G. A., Fischer, A. R., Tobi, H., \& van Trijp, H. C. (2017). Explicit and implicit attitude toward an emerging food technology: The case of cultured meat. Appetite, $108,245-254$.

Bianchi, F., Garnett, E., Dorsel, C., Aveyard, P., \& Jebb, S. A. (2018). Restructuring physical micro-environments to reduce the demand for meat: a systematic review and qualitative comparative analysis. The Lancet Planetary Health, 2(9), e384-e397. doi:10.1016/S2542-5196(18)30188-8

Blanton, H., \& Gerrard, M. (1997). Effect of sexual motivation on men's risk perception for sexually transmitted disease: There must be 50 ways to justify a lover. Health Psychology, 16(4), 374. doi: 10.1037/0278-6133.16.4.374

Bohrer, B. M. (2019). An investigation of the formulation and nutritional composition of modern meat analogue products. Food Science and Human Wellness, 8(4), 320329.

Brown, C. (2015). Fish intelligence, sentience and ethics. Animal cognition, 18(1), 117. doi:10.1007/s10071-014-0761-0 
Bryant, C. J. (2019). We can't keep meating like this: Attitudes towards vegetarian and vegan diets in the United Kingdom. Sustainability, 11(23), 6844.

Bryant, C. (2019). Reducing Animal Product Consumption: Studies of UK MeatEaters. Bristol: Viva! Available at https://osf.io/ck38r/

Bryant, C., \& Sanctorum, H. (2021). Alternative proteins, evolving attitudes: Comparing consumer attitudes to plant-based and cultured meat in Belgium in two consecutive years. Appetite, 161, 105161. doi:10.1016/j.appet.2021.105161

Bryant, C., Szejda, K., Parekh, N., Deshpande, V., \& Tse, B. (2019). A survey of consumer perceptions of plant-based and clean meat in the USA, India, and China. Frontiers in Sustainable Food Systems, 3, 11.

Buddle, E. A., Bray, H. J., \& Ankeny, R. A. (2018). Why would we believe them? Meat consumers' reactions to online farm animal welfare activism in Australia. Communication Research and Practice, 4(3), 246-260.

https://doi.org/10.1080/22041451.2018.1451209

Cohen, J. (1992). A power primer. Psychological bulletin, 112(1), 155.

Compassion in World Farming. (n.d.) Do you live in a factory farm hotspot? Available at https://www.ciwf.org.uk/factory-farm-map/

Dillard, J. (2008). A slaughterhouse nightmare: Psychological harm suffered by slaughterhouse employees and the possibility of redress through legal reform. Georgetown Journal on Poverty Law \& Policy, 15, 391.

Faunalytics. (2014). Video Comparison Study: Youth Response to Four Vegetarian/Vegan Outreach Videos. Retrieved December 03, 2020, from https://faunalytics.org/video-comparison-study-youth-response-to-fourvegetarianvegan-outreach-videos/

Fiorentini, M., Kinchla, A. J., \& Nolden, A. A. (2020). Role of Sensory Evaluation in Consumer Acceptance of Plant-Based Meat Analogs and Meat Extenders: A Scoping Review. Foods, 9(9), 1334.

Fotopoulos, C., Krystallis, A., Vassallo, M., \& Pagiaslis, A. (2009). Food Choice Questionnaire (FCQ) revisited. Suggestions for the development of an enhanced general food motivation model. Appetite, 52(1), 199-208.

doi:10.1016/j.appet.2008.09.014 
Gallup. (2020). Four in 10 Americans Have Eaten Plant-Based Meats. Retrieved 25 February 2021 from https://news.gallup.com/poll/282989/four-americans-eaten-plantbased-meats.aspx

Garnett, E. E., Balmford, A., Sandbrook, C., Pilling, M. A., \& Marteau, T. M. (2019). Impact of increasing vegetarian availability on meal selection and sales in cafeterias. Proceedings of the National Academy of Sciences, 116(42), 20923-20929. doi:10.1073/pnas.1907207116

Gaspar, R., Luís, S., Seibt, B., Lima, L., Marcu, A., Rutsaert, P., Fletcher, D., Verbeke, D., \& Barnett, J. (2016). Consumers' avoidance of red meat risks: effects on attitudes and perceived knowledge. Journal of Risk Research, 19, 533-549. doi:10.1080/13669877.2014.1003318

Hoek, A.C.; Luning, P.A.; Weijzen, P.; Engels, W.; Kok, F.J.; \& De Graaf, C. (2011). Replacement of meat by meat substitutes. A survey on person-and product-related factors in consumer acceptance. Appetite, 56, 662-673.

https://doi.org/10.1016/j.appet.2011.02.001

Humane League Labs. (2014a). Diet Change and Demographic Characteristics of Vegans, Vegetarians, Semi-Vegetarians, and Omnivores. Available at http://www.humaneleaguelabs.org/static/reports/2014/04/diet-change-anddemographic-characteristics1.pdf

Humane League Labs (2014b). Report: What Cover Photos Make People Most Interested In Reading Pro-Veg Literature? Retrieved December 03, 2020, from https://osf.io/t25qz/

Hunter, E., \& Röös, E. (2016). Fear of climate change consequences and predictors of intentions to alter meat consumption. Food Policy, 62, 151-160.

doi:10.1016/j.foodpol.2016.06.004

IPCC (Intergov. Panel Clim. Change). (2018). Global Warming of $1.5^{\circ} \mathrm{C}$. An IPCC Special Report on the Impacts of Global Warming of $1.5^{\circ} \mathrm{C}$ Above Pre-Industrial Levels and Related Global Greenhouse Gas Emission Pathways, in the Context of Strengthening the Global Response to the Threat of Climate Change, Sustainable Development, and Efforts to Eradicate Poverty.

https://www.ipcc.ch/site/assets/uploads/sites/2/2019/06/SR15 Full Report High Re s.pdf

Januszewska, R., Pieniak, Z., \& Verbeke, W. (2011). Food choice questionnaire revisited in four countries. Does it still measure the same?. Appetite, 57(1), 94-98. https://doi.org/10.1016/j.appet.2011.03.014 
Landers, T. F., Cohen, B., Wittum, T. E., \& Larson, E. L. (2012). A review of antibiotic use in food animals: perspective, policy, and potential. Public health reports, 127(1), 4-22. https://doi.org/10.1177/003335491212700103

Lee, C. R., Cho, I. H., Jeong, B. C., \& Lee, S. H. (2013). Strategies to minimize antibiotic resistance. International journal of environmental research and public health, 10(9), 4274-4305. https://doi.org/10.3390/ijerph10094274

Loughnan, S., Haslam, N., \& Bastian, B. (2010). The role of meat consumption in the denial of moral status and mind to meat animals. Appetite, 55(1), 156-159. https://doi.org/10.1016/i.appet.2010.05.043

Low, P., Panksepp, J., Reiss, D., Edelman, D., Van Swinderen, B., \& Koch, C. (2012, July). The Cambridge declaration on consciousness. In Francis Crick memorial conference, Cambridge, England (pp. 1-2).

McEachern, M. G., \& Seaman, C. (2005). Consumer perceptions of meat production. British Food Journal, 107(8), 572-593. doi:10.1108/00070700510610986

McEwen, S. A. (2006). Antibiotic use in animal agriculture: what have we learned and where are we going?. Animal biotechnology, 17(2), 239-250.

https://doi.org/10.1080/10495390600957233

Michel, F., Hartmann, C., \& Siegrist, M. (2021). Consumers' associations, perceptions and acceptance of meat and plant-based meat alternatives. Food Quality and Preference, 87, 104063. doi:10.1016/j.foodqual.2020.104063

Ngapo, T. M., Dransfield, E., Martin, J. F., Magnusson, M., Bredahl, L., \& Nute, G. R. (2003). Consumer perceptions: pork and pig production. Insights from France, England, Sweden and Denmark. Meat Science, 66(1), 125-134. doi:10.1016/S03091740(03)00076-7

O'Neill, J. (2015). Antimicrobials in agriculture and the environment: reducing unnecessary use and waste. The review on antimicrobial resistance, 1-44. Retrieved November 26, 2020, from

https://amr-

review.org/sites/default/files/Antimicrobials\%20in\%20agriculture\%20and\%20the\%20 environment\%20-\%20Reducing\%20unnecessary\%20use\%20and\%20waste.pdf

Odegard, I. \& Sinke, P. (2021). LCA of cultivated meat. Future projections for different scenarios. CE Delft \& the Good Food Institute. Available at https://cedelft.eu/publications/rapport-lca-of-cultivated-meat-future-projections-fordifferent-scenarios/ 
Onwezen, M. C., \& van der Weele, C. N. (2016). When indifference is ambivalence: Strategic ignorance about meat consumption. Food Quality and Preference, 52, 96105. https://doi.org/10.1016/j.foodqual.2016.04.001

Petersen, T., Hartmann, M., \& Hirsch, S. (2021). Which meat (substitute) to buy? Is Front of Package Information reliable to identify the healthier and more natural choice?. Food Quality and Preference, 104298.

Poore, J., \& Nemecek, T. (2018). Reducing food's environmental impacts through producers and consumers. Science, 360(6392), 987-992.

Post, M. J., Levenberg, S., Kaplan, D. L., Genovese, N., Fu, J., Bryant, C. J., ... \& Moutsatsou, P. (2020). Scientific, sustainability and regulatory challenges of cultured meat. Nature Food, 1(7), 403-415.

Reese. J. (2017, November 20). Survey of US Attitudes Towards Animal Farming and Animal-Free Food October 2017. Sentience Institute. Accessed 30 November 2020 at https://www.sentienceinstitute.org/animal-farming-attitudes-survey-2017

Rosenfeld, D. L., \& Tomiyama, A. J. (2020). Taste and health concerns trump anticipated stigma as barriers to vegetarianism. Appetite, 144, 104469.

doi:10.1016/j.appet.2019.104469

Rothgerber, H. (2020). Meat-related cognitive dissonance: A conceptual framework for understanding how meat eaters reduce negative arousal from eating animals. Appetite, 146, 104511.

Saerens, W., Smetana, S., Van Campenhout, L., Lammers, V., \& Heinz, V. (2021). Life cycle assessment of burger patties produced with extruded meat substitutes. Journal of Cleaner Production, 306, 127177.

Saget, S., Costa, M., Santos, C. S., Vasconcelos, M. W., Gibbons, J., Styles, D., \& Williams, M. (2021). Substitution of beef with pea protein reduces the environmental footprint of meat balls whilst supporting health and climate stabilisation goals. Journal of Cleaner Production, 297, 126447.

Sanchez-Sabate, R., \& Sabaté, J. (2019). Consumer attitudes towards environmental concerns of meat consumption: A systematic review. International Journal of environmental research and public health, 16(7), 1220. https://doi.org/10.3390/ijerph16071220

Sanders, B. (2020). Global Animal Slaughter Statistics \& Charts: 2020 Update [web log]. https://faunalytics.org/global-animal-slaughter-statistics-and-charts-2020update/. 
Sneddon, L. (2015). Pain in aquatic animals. Journal of Experimental Biology 218: 967-976. doi:10.1242/jeb.088823

Steptoe, A., Pollard, T. M., \& Wardle, J. (1995). Development of a measure of the motives underlying the selection of food: the food choice questionnaire. Appetite, 25(3), 267-284.

Tappin, B. M., \& McKay, R. T. (2017). The illusion of moral superiority. Social Psychological and Personality Science, 8(6), 623-631.

https://doi.org/10.1177/1948550616673878

Turnwald, B. P., Boles, D. Z., \& Crum, A. J. (2017). Association between indulgent descriptions and vegetable consumption: Twisted carrots and dynamite beets. JAMA internal medicine, 177(8), 1216-1218. doi:10.1001\%2Fjamainternmed.2017.1637

Vennard D., T. Park, and S. Attwood. (2018). Encouraging Sustainable Food Consumption by Using More-Appetizing Language. World Resources Institute. https://www.wri.org/publication/encouraging-sustainable-food-consumption-usingmore-appetizing-language

Which? (2018, May 23). Brexit Consumer Research Topic of focus: Food.

https://production-which-

dashboard.s3.amazonaws.com/system/articles/attachments/1/Brexit and Food Apri 2018 FINAL.pdf

Woolley, K., \& Risen, J. L. (2018). Closing your eyes to follow your heart: Avoiding information to protect a strong intuitive preference. Journal of personality and social psychology, 114(2), 230. https://doi.org/10.1037/pspa0000100 